\title{
PHARMACOLOGICAL STUDY ON THE EFFECT OF DICLAZURIL AND FLAVOMYCIN ON THE IMMUNE RESPONSE IN CHICKENS
}

\author{
Abdel-Aziz, M.I ${ }^{1}$, Zahra, A.A. ${ }^{1}$, El-Seedi, I.A. ${ }^{2}$ and Ghada Abdel-Hafez ${ }^{2}$ \\ ${ }^{1}$ Pharmacology Dep., Fac. of Vet. Med., Tanta University (Kafr El-Sheikh) \\ ${ }^{2}$ Animal Health Research Institute, El-Dokki, Giza
}

\begin{abstract}
The present study was conducted to evaluate diclazuril at the recommended and its two folds doses ( $1 \& 2$ ppm), flavomycin at 75 gm/ton and their combinations on the immune response in chickens vaccinated with IBD vaccine. Diclazuril displayed a dose dependent immunity suppression. In the recommended dose, it did not harm the bird immunity. While, in double recommended dose, it significantly suppressed the chicken immune response to IBD virus vaccine. The depressed response was reflected as a decreased bursal weight, skin hypersensitivity, total leucocytic count, lymphocyte count, antibody titer, serum protein and serum globulins. While, flavomycin at 75 $\mathrm{gm} / \mathrm{ton}$ had no detectable effect on the bird immune response to IBD virus vaccine.The combinations between diclazuril (as an anticoccidial drug) and flavomycin (as a growth promotor) have no drug interaction in our experiment.
\end{abstract}

\section{INTRODUCTION}

Efficient control of infectious diseases in poultry depends on adequate flock-immunity.Reduced immune responsivness, leading to increased disease losses, can seriously damage poultry industry. Severe outbreaks and heavy losses that occur among vaccinated birds are often blamed to immunosuppression (Giambrone, 1989). Using some drugs administered prior or post vaccination could be one of the foremost causes of immunosuppression(Davis et al.1973). Additionally, a wide variety of antimicrobial and chemotherapeutic drugs do impose significantimmunosuppressive effects(Biondi and Sachiavo 1965; Nikolaev and Nazarmukhamedova 1974; Shalaby et al. 1993). 
In modern broiler management, preventive measures are taken to control economically important diseases such as coccidiosis and bacterial enteritis, which reduce feed utilization and live performance characteristics. Chemotherapeutic and antibiotic feed additives are frequently used for disease prevention and treatment (e.g. diclazuril) or improvement of nutritional performance and intestinal health (e.g.flavomycin). Although, diclazuril (a potent new broad spectrum anticoccidial agent) and flavomycin (a growth promoter antibiotic) are used on a large scale worldwide, their effects on the bird immune status are not clearly studied. Stemmed from previous notion, the present study was conducted to evaluate diclazuril at the recommended and its two folds doses ( $1 \& 2 \mathrm{ppm})$, flavomycin at $75 \mathrm{gm} /$ ton and their combinations on the immune response in chickens vaccinated with IBD vaccine.

\section{MATERIALS AND METHODS}

Diclazuril (Clinacox ${ }^{\circledR}$ ) is a trade name registered by JANSSEN Animal Health Pharmaceutica Co. It is an anticoccidial drug belonging to benzene acetonitril group. It is potential as an effective agent against all major pathogenic Eimeria species in chicken when added to the feed at a level of $1 \mathrm{ppm}$.

Flavomycin (Flavomycin ${ }^{\circledR}$ ) is a trade name registered by Intervet pharmaceutica Co. It is phosphoglycolipid antibiotic produced by four streptomyces strains and used solely as a promotor of performance and not as a therapeutic agent. It administered via the feed at a rate of $75-120$ $\mathrm{gm} / \mathrm{ton}$.

\section{Birds, experimental grouping and blood sampling:}

One hundred and forty healthy, one-day old Hubbard broiler chicks were obtained from 'Star farms Co, Tanta, Egypt. The chicks were reared in floor pens under complete hygienic conditions. Throughout the whole experiment, the birds were fed on a balanced commercial starter poultry ration $(21.9 \%$ protein, $6.9 \%$ fat, and $3.5 \%$ fibers) free from any 
medication or antimicrobial additives, obtained from El-Kahera Poultry Ration Processing Co, Tanta, Egypt. Food and water were provided ad libitum throughout the experiment. Rooms were electrically heated and conditions of constant light were employed.

The birds were divided into seven groups, each of twenty chicks. From the first day of age, the first group received $1 \mathrm{ppm}$ diclazuril, the second group received $2 \mathrm{ppm}$ diclazuril, the third group received $1 \mathrm{ppm}$ diclazuril and $75 \mathrm{gm} /$ ton flavomycin, the fourth group received $2 \mathrm{ppm}$ diclazuril and $75 \mathrm{gm} /$ ton flavomycin and the fifth group received only 75 gm/ton flavomycin. While, the sixth and seventh groups were fed on drug free ration (basal diet). With exception of the sixth group, at the $14^{\text {th }}$ and $21^{\text {st }}$ day of age all the birds were vaccinated with TAD Gumboro vaccine via eye drop instillation (El-Khayat 2003). The birds of sixth group remained unvaccinated and served as a negative control, while, the chicks of the seventh group served as a positive control. As the IBD antibody titer reaches its peak after 2-3 weeks from the second vaccination (El-Khayat 2003), 5 birds from each group at $38^{\text {th }}$ day of age were accurately marked, challenged with virulent $G 10^{8}$ Gomboro virus (250 $\mu$ l of 1:50 dilution) via eye instillation and kept under observation for the next 5 days. Other 5 birds from each group at $38^{\text {th }}$ day of age were used for skin hypersensitivity test. At the end of the experiment, birds were weighted before slaughter and after slaughtering bursa of Fabricous was eviscerated and weighted to the nearest $0.1 \mathrm{~g}$. The bursal/body weight ratio for each bird was calculated by dividing the bursal weight on the live weight and multiplied by 100 .

At $21^{\text {st }}, 28^{\text {th }}, 35^{\text {th }}$ and at $42^{\text {nd }}$ days blood samples were collected from the wing vein of chickens (10 bird/group). Each blood sample was $5 \mathrm{ml}$ subdivided into two sub-samples. The first sub-samples were of 0.5 $\mathrm{ml}$ and collected in $1.5 \mathrm{ml}$ clean dry Eppendorf tubes containing EDTA (1 $\mathrm{mg} / \mathrm{ml}$ fresh blood, Schalm et al. 1975) to be used for the total and 
differential leucocytic counts. The second sub-sample was of $4.5 \mathrm{ml}$ and collected in a clean sterilized $10 \mathrm{ml}$ centrifuge tubes without anticoagulant. The blood was allowed to coagulate at room temperature for one hour and then centrifuged at $3000 \mathrm{rpm}$ for $10 \mathrm{~min}$ to separate the serum. The supernatant clear serum was collected and subdivided into two aliquots into two Eppendorf tubes, one was used for serological tests and the second for measuring the serum total proteins and protein electrophoretic pattern. Thereafter, the serum was immediately frozen and stored at $-20{ }^{\circ} \mathrm{C}$.

\section{Effects on immune response:}

\section{A- Skin test for delayed hypersensitivity:}

For studying the effect of diclazuril, flavomycin and their combinations on the delayed hypersensitivity of chickens to sheep RBCs, the intradermal wattle test was used as described by Afiefy (1986). Five $\mathrm{ml}$ blood sample was collected from jagular vein of healthy sheep in a centrifuge tube containing sodium citrate.The concentration of RBCs was calculated by using haemocytometer. Then, the blood sample was centrifuged at 1500 rpm for $15 \mathrm{~min}$ and washed with physiological saline. Washing and centrifugation was repeated 3 times. Thenafter, the RBCs were diluted in sterile physiological saline solution to a final concentration of $1 \times 10^{7} / \mathrm{ml}$.

Thirty five chicks ( 5 from each group) were used at 45 day old. The cocks were injected intradermally in the right wattle with $0.1 \mathrm{ml}$ of the diluted previously prepared sheep RBCs. The left wattle was left as negative control (injected intradermally with $0.1 \mathrm{ml}$ sterile physiological saline solution). The wattle thickness was measured with skinfold caliber before and daily after injection for 4 consecutive days. The increase in the wattle thickness was calculated by substracting the thickness of the wattle before injection from that after injection. 


\section{B- Cellular immunity:}

Total Leucocytic count (TLC) of the chicken blood samples was carried out as described by Natt and Herrick (1952) using improved Neubauer chamber. Differential leucocytic count (DLC) was determined according to Schalm et al. (1975).

\section{$C$ - Humoral immunity:}

The influence of diclazuril, flavomycin and their combinations on humoral immune response of the birds vaccinated with TAD Guomboro vaccine was evaluated by determination of antibody titer by Indirect enzyme linked immunosorbent assay(ELISA)as described by Lamichhane et al. (2000), total serum proteins by biuret technique after Doumas et al. (1981) and fractionation of serum proteins by polyacrylamide gel electrophoresis using the continuous buffer system of Davis(1964)and Ornstein (1964).

\section{Statistical analysis:}

Data are represented as mean \pm S.D. Metrical data were normalized by logarithmic transformation. Analysis of variance (ANOVA) was used for comparison of mean values of the various treatments at a significance level of $P<0.05$. Statistical analysis was performed by using 'SPSS-10' computer program (Sokal and Rohlf 1995).

\section{RESULTS}

\section{Challenge test, skin hypersensitivity and bursal weight:}

All the five chicks of non-vaccinated non-medicated group died within 3 days after experimental infection. All the medicated bird groups showed non-significant differences in mortality ratio (20-40\%) than the vaccinated non-medicated control group. 
In the first 2 days after intradermal injection of sheep RBCs, the vaccinated non-medicated group and the medicated groups with $1 \mathrm{ppm}$ diclazuril, $75 \mathrm{~g} /$ ton flavomycin and their combination showed significant increases in wattle thickness than that of non-vaccinated non-medicated group. While, chicken medicated with $2 \mathrm{ppm}$ diclazuril alone or in combination with $75 \mathrm{~g} \backslash$ ton flavomycin showed non-significant changes and significant decreases in wattle thickness than that in non-vaccinated nonmedicated and vaccinated non-medicated control groups, respectively (Table 1).

Non-vaccinated non-medicated group and the groups medicated with $2 \mathrm{ppm}$ diclazuril alone or in combination with flavomycin 75 $\mathrm{gm} /$ ton showed significant decreases in bursal weight and relative bursal weight than those of vaccinated non-medicated group and the medicated groups with $1 \mathrm{ppm}$ diclazuril, $75 \mathrm{~g} / \mathrm{ton}$ flavomycin and their combination (Fig 1).

\section{Cellular immunity:}

Throughout the whole experiment, Non-vaccinated non-medicated group and the groups medicated with $2 \mathrm{ppm}$ diclazuril alone or in combination with flavomycin $75 \mathrm{gm} /$ ton showed significant decreases in total leucocytic counts compared with the vaccinated non-medicated group and the medicated groups with $1 \mathrm{ppm}$ diclazuril, $75 \mathrm{~g} /$ ton flavomycin and their combination. While, groups medicated with $2 \mathrm{ppm}$ diclazuril alone (group 2) or in combination with flavomycin $75 \mathrm{~g} /$ ton (group 4) showed significant decreases in total leucocytic count compared with the vaccinated non-medicated control group throughout the whole measurements (Table 2).

Throughout the whole measurements, there were non-significant differences in the ratios of heterophiles, monocytes, basophiles and eosinophiles in non vaccinted non-medicated group, vaccinated non- 
medicated group and all medicated vaccinated experimental groups. While the ratio of lymphocytes showed significant decreases in nonvaccinated non-medicated group and in medicated groups with $2 \mathrm{ppm}$ diclazuril alone or in combination with $75 \mathrm{~g} /$ ton flavomycin than in vaccinated non-medicated group (Table 3).

\section{Humoral immunity:}

Non-vaccinated non-medicated group showed significant decreases in antibody titer, total serum proteins, and serum globulins than those of vaccinated non-medicated group throughout the experiment (Tables 4, 5, $6,7 \& 8)$.

Throughout the whole recording, chicken medicated with $1 \mathrm{ppm}$ diclazuril, 75 glton flavomycin and their combination showed nonsignificant changes in antibody titer, total serum proteins and serum globulins than those of vaccinated non-medicated control. While, chicken medicated with 2 ppm diclazuril alone or in combination with $75 \mathrm{~g} /$ ton flavomycin showed significant decreases in antibody titer, total serum proteins and serum globulins than in vaccinated non-medicated control group (Tables 4, 5, 6, $7 \& 8$ ).

Serum albumin levels showed non-significant changes between all experimental chicken groups throughout the whole experiment (Fig 2).

\section{DISCUSSION}

This work was done for studying the effect of diclazuril as a commercially used coccidiostat, flavomycin as a growth promotor and their combinations on immune status after vaccination with IBD virus vaccine. The parameters considered for the purpose of this study included skin hypersensitivity, total and differential leucocytic counts, total and fractionation of serum proteins. 
Birds vaccinated with IBD vaccine and administered diclazuril in both recommended dose and its twofold displayed mortality rate of $20 \%$ and $40 \%$, respectively against challenge with velogenic $\mathrm{G}$ strain of IBD virus, versus a mortality rate of $20 \%$ in the vaccinated non-medicated birds. Non-vaccinated non-medicated birds displayed $100 \%$ mortality rate in response to challenge with velogenic $G$ strain. The previous findings coincide with the fact that the percentage of mortality rate evoked by experimental infection was non-significantly increased in the birds administered the double recommended dose of diclazuril. On similar grounds it has been documented that double the recommended dose of diclazuril did not reduce the bird performance (Hasan et al. 1999; Kandeel 2002).

Birds vaccinated with IBD vaccine and administered flavomycin displayed mortality rate of $20 \%$ similar to the control vaccinated non medicated birds. This is in full agreement with the recordings of Dost (1991) in chickens, and Parks et al. (2001) in turkeys and disagree with the recordings of Dash et al. (1992) and Abd Allah (2002) who reported that mortality rate was decreased significantly in the flavomycin medicated group than in the control non medicated birds. This disagreement may be due to dose and environmental variations.

Our results showed that chicks medicated with $1 \mathrm{ppm}$ diclazuril, $75 \mathrm{gm} /$ ton flavomycin and their combination had no deviation in bursal weight, relative bursal/body weight and skin hypersensitivity from those of control vaccinated non-medicated group. These results are in the same line with our results on the total and differential leucocytic counts indicating that diclazuril at $1 \mathrm{ppm}$ and flavomycin at $75 \mathrm{~g} / \mathrm{ton}$ had no effect on the cellular immunity. These results are in full agreement with that reported by Hussein (2002) and Kandeel (2002) for diclazuril and Jamroz et al (1992) for flavomycin. 
Groups medicated with the double recommended dose of diclazuril (2 ppm) showed significant decreases in bursal weight, relative bursal / body weight and skin hypersensitivity. Generally, high doses of anticoccidial drugs inhibit the cellular immunity in the form of decrease in the weight of lymphoid organs (bursa and thymus) (Shalaby et al. 1993) and skin delayed hypersensitivity (Hasan et al. 1999).

Our results showed that diclazuril affect the total leucocytic count and lymphoctic counts in two different ways depending on the medication dose. At the recommended medication dose $(1 \mathrm{ppm})$, it showed no deviation than the control vaccinated non-medicated control group. While at the double recommended dose ( $2 \mathrm{ppm})$ it had a suppressive effect on the total leucocytic and lymphoctic counts compared with that of the vaccinated non-medicated control group. These results are in agreement with Hasan et al. (1999) and Kandeel (2002). This suppression effect may be due to that high doses of anticoccidials may cause immunosuppression (Karlson and Malcolm 1978) and adversely affect the cellular immunity (Hasan et al. 1999). These findings disagree with Hamoud (1994) who found that in rabbits there were non-significant differences in total leucoytic counts between all diclazuril medicated groups and the control group throughout the whole experiment. This disagreement may be due to the different animal species. Also, It has been shown that the lymphocyte counts were significantly increased in the vaccinated birds starting from $21^{\text {st }}$ day of age till the end of the experiment. These results are in full agreement with Stites (1980) who reported that lymphocyte transformation and proliferation in vitro occur following their exposure to viral antigen (e.g IBD virus vaccine).

Flavomycin had no effect on the total and differential leucocytic count which is in agreement with the results of Jamroz et al. (1992) in total leucocytic counts and Dash et al. (1992) in PCV (\%). This may be

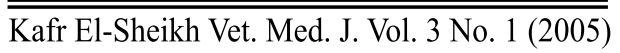


resulting from that, flavomycin is not absorbable from the intestine and acting through the enhancement of the normal avian gut flora (Hambert et al. 1991).

The present results showed that diclazuril medication affected the serum antibody titer of IBD in different ways depending on the medication dose. At a dose of $1 \mathrm{ppm}$ diclazuril,there were non-significant differences in antibody titer between medicated birds and the control vaccinated nonmedicated birds. This is indicating that diclazuril at that dose level has no effect on the humoral immunity.This finding is in harmony with the findings of Hasan et al. (1999) in rabbits and Hussein (2002) in chickens.

Diclazuril at $2 \mathrm{ppm}$ had a negative effect on the antibody titer of IBD virus, indicating that diclazuril at double the recommended dose has a suppressive effect on the bird humoral immunity. These results agree with that reported by Hasan et al. (1999) in rabbits. Also, similar findings were previously proved with high doses of other anticoccidials as lasolacid (Abd El-Aziz and Agag 1991), salinomycin (Shalaby et al. 1993) and semduramicin (El-Kahky 1998; Kandeel 2002).

The effect of diclazuril on the total serum proteins and serum globulins were varied in the present study. At a dose of $1 \mathrm{ppm}$, there were non-significant differences between the vaccinated, medicated group and the vaccinated non-medicated control group. Indicating that diclazuril at that dose level had no adverse effect on serum total proteins and serum globulins and subsequently on the humoral immunity. These findings are in harmony with our results related to antibody titer of IBD virus. Similar results were previously detected in chickens (Hussein 2002; Kandeel 2002) and in rabbits (Hamoud 1994). While the groups medicated with 2 ppm diclazuril showed significant decreases in the total serum proteins and serum globulins than in non-medicated control group indicating that $2 \mathrm{ppm}$ diclazuril has a negative effect on serum proteins Kafr El-Sheikh Vet. Med. J. Vol. 3 No. 1 (2005) 
and consequently on bird immunity. These results are in agreement with semduramicin reported by $\boldsymbol{E l} \boldsymbol{K a h k y ~ ( 1 9 9 8 )}$ and disagree with that of Hamoud (1994) in rabbit. This disagreement may be due to different animal species.

Flavomycin did not affect the the antibody titer of IBD virus and total serum proteins indicating that flavomycin has no effect on the humeral immunity. This may be due to large molecules of flavomycin which are not absorbable from the intestine (Hambert et al. 1991). Flavomycin had no effect on both cellular and humoral immunity in our present study. These results can give an explanation to that reported by Brenes et al (1989) who demonstrated that inclusion of flavomycin in chick diets did not influence the composition of intestinal microflora which included coliforms, lactobacilli, enterococci and $C$. perfringens. Moreover, Fairchild et al (2001) found that flavomycin altered the intestinal and liver bacterial populations only transiently. Recently, Martel et al. (2004) noticed that flavomycin has no activity against the isolated intestinal strains of $C$. perfringens in chickens.

Our results showed that the combinations between diclazuril as an anticoccidial drug and flavomycin as a growth promoter antibiotic have no drug-drug interaction. These results are in the same line with that previously detected between salinomycin as an anticoccidial drug and flavomycin (Palic et al. 1998). They reported that the chicken group medicated with the combination of salinomycin and flavomycin showed siginificant increase in bird performance in comparison with the control non-medicated group and the group medicated with salinomycin only. Indicatively, that salinomycin did not interact or interfere with the effect of flavomycin. Generally, the combination between chemotherapeutics and antibiotics as feed additives to animals is still under discussion (Bolder et al., 1999) and require more detailed studies. 


\section{REFERENCES}

- Abd Allah, M. F. (2002): Comparative study on the antibiotics flavomycin \& enramycin and the probiotics bio-nutra $\&$ dinaferm as growth promoters in broilers. A thesis for M.V.Sc. (pharmacology), Faculty of Veterinary Medicine, Tanta University.

- Abd El-Aziz, M.I. and Agag, A.E. (1991): Effect of lasolocid on immune response to NewCastle disease vaccine virus in chickens. Vet. Med. Res., 1: 171-182.

- Afiefy, N.A. (1986): Effect of some drugs on the immune response to NewCastle disease vaccine in chickens. A thesis for Ph.D. (pharmacology), Faculty of Veterinary Medicine, Cairo University.

- Biondi, E. and Sachiavo, A. (1965): Effect of some coccidiostats on production of NewCastle haemagglutination inhibition antibodies. Acta Med. Vet., 11: 159-168.

- Bolder, N.M., Wagenaar, J.A., Putirulan, F.F., Veldman, K.T. and Sommer, M. (1999): The effect of flavophospholipol (Flavomycin ${ }^{\circledR}$ ) and salinomycin sodium $\left(\operatorname{Sacox}{ }^{\circledR}\right)$ on the excretion of Clostridium perfringens, Salmonella enteritis, and Campylobacter jejuni in broilers after experimental infection. Poult. Sci., 78: 1681-1689.

- Brenes,A.,Trevino, J.,Centeno, C. and Yuste, P. (1989): Influence of peas (Pisum sativum) as a dietary ingredient and flavomycin supplementation on the performance and intestinal microflora of broiler chicks. Br. Poult. Sci., 30: 81-89.

- Dash, P.K., Verma, S.V.S., Mahaparta, C.M. and Gopal, R. (1992): Response of broilers to certain performance promotors. Ind. J. Poult. Sci., 27 (2): 113-115.

- Davis, B.D., Dulbecco, R., Eisen, H.N., Ginsberrg, H.S. and Wood, W.B. (1973): Effect of drugs on immune response of poultry. Microbiology, $2^{\text {nd }}$ Ed. Harper and Row publisher.

- Davis, P.Z. (1964): Disc-electrophoresis II- Method and application to human serum protein. Ann. N. Y. Acd. Sci., 121: 404-409. 
- Dost, G. (1991): Effect of feeding flavophospholipol to broilers over 20-years period (beginning 1962 and ending 1981). Medicine Veterinaria, 8: 103-110.

- Doumas, B.T., Bayso, D.D., Carter, R.J., Peter, S.T. and Schffer, R. (1981): Determination of serum total protein. J. Biol. Chem. 98: 710-719.

- El- Kahkey, M. (1998): Effect of semiduramicin on the immune response in chickens vaccinated with NewCastle disease virus. A thesis for Ph.D. (pharmacology), Faculty of Veterinary Medicine, Zagazig University.

- El-Khayate, F.A. (2003): Evaluation of some vaccination programs against infectious bursal disease (Gumboro) in Egypt. A thesis for Ph.D. (poultry diseases), Faculty of Veterinary Medicine, Tanta University.

- Fairchild, A.S., Grimes, J.L., Jones, F.T, Wineland, M.J., Edens, F.W. and Sefton, A.E. (2001): Effects of hen age, Bio-Mos ${ }^{\circledR}$ and Flavomycin $^{\circledR}$ on poult susceptibility to oral Escherichia coli challenge. Poult. Sci., 80: 562-571.

- Giambrone, J.J. (1989): Review on immunosuppression of poultry. Momentum technical information for MSD agvet., 1: 5-9.

- Hambert,F., Lalande, F., L'Hospitalier, R., Salvat, G. and Bennejean, G. (1991): Effect of four antibiotic additives on Salmonella contamination of chicks protected by an adult caecal flora. Avian Pathol., 20: 577-584.

- Hamoud, M.M. (1998): Studies on the efficacy of commercially used coccidiostats in the prevention of rabbit coccidiosis. A thesis for M.V.Sc. (poulty diseases), Faculty of Veterinary Medicine, Cairo University.

- Hasan, S., El-Sabbagh, F. and Hesham, S. (1999): Effect of diclazuril on performance and immune response in rabbits. Al-Azhar Med. J., 28 (2): 183-191.

- Hussein, M.S. (2002): Hematological, serum biochemical and histopatholo-gical studies on chicken treated with anticoccidial 
drugs.A thesis for M.V.Sc. (clinical pathology), Faculty of Veterinary Medicine, Tanta University.

- Jamroz, V.D., Skorupinska, J., Wiliczkiewicz, A. and Schleicher, A. (1992): Influence of feed composition and antibiotic growth promotors on chemical and morphological blood parameters and histological changes of the small intestine in broilers. Wien. Tierärztl. Mschr., 79: 13-19.

- Kandeel, M. (2002): The effect of diclazuril and semiduramicin as prophyl-actic and therapeutic treatments on broilers infected with Eimeria tenella. A thesis for M.V.Sc. (pharmacology), Faculty of Veterinary Medicine, Tanta University.

- Karlson, T. and Malcolm, W. (1978): Development of immunity to coccidiosis in chicken administered anticoccidials in feed. Avian Dis., 22: 487-495.

- Lamichhane, C.M., Jerome, L. and Adenikinju, S. (2000): ELISA for the detection and differentiation of infectious bursal disease virus. Presented at $49^{\text {th }}$ western poultry disease conference, Sacramento, CA. 2000.

- Martel, A., Devriese, L.A., Cauwerts, K., De Gussem, K., Decostere, A. and Haesebrouck, F. (2004): Susceptibility of Clostridium perfringens strains from broiler chickens to antibiotics and anticoccidials. Avian Pathol., 33 (1): 3-7.

- Natt, M.P. and Herrick, C.A. (1952): A new blood diluent for counting the erythrocytes and leucocytes of chickens. Poult. Sci., 31: 735-738.

- Nikolaev, A.I. and Nazarmukhamedova, M.N.(1974): Effect of streptom-ycin and oxytetracycline on the number of antibody forming cells and haem-agglutinin titer in immunized animals. Epidemiol. Immunology,II (8): 83-95.

- Ornstein, L.C. (1964): Disc-electrophoresis I- Background and theory. Ann. N. Y. Acd. Sci., 121: 212-221.

- Palic, T., Stankovic, G. and Novakovic, Z. (1998): Effect of simultaneous application of Sacox and Flavomycin preparations on broiler performance and health. Zivinarstvo, 33: 211-214.

- Parks, C.W., Grimes, J.L., Ferket, P.R. and Fairchild, A.S. (2001): The effect of mono-oligosaccharides, bambermycin and 
virginamycin on perfor-mance of large white male market turkeys. Poult. Sci., 80 (6): 718-723.

- Schalm,O.W.,Jain, N.C.and Carroll,E.J. (1975): Veterinary Haematology, $3^{\text {rd }}$ Ed. Lea and Febiger, Philadelphia.

- Shalaby, M.A., El-Sanousi, A.A., Yehia, M.M., Naser, A. and Reda, I.M. (1993): The effect of salinomycin on the immune response of chicks. Deutsch Tieraerztl. Wschr., 100 (5): 182-185.

- Sokal, R.R. and Rohlf, J. (1995): Biometry. $3^{\text {rd }}$ Ed. W.H. Freeman and Company, New York.

- Stites,D.P.(1980): Clinical laboratory methods of detecting cellular immune function. In Basic and Clinical Immunology, edited by H.H. Fudenberg, D.P. Stites, J.L.Calwell and J.V. Wells. PP. 382-397. Large Medical Publications, Los Altos, California.

در اسة فارماكولوجية لاستبيان تاثثر عقاري الدايكلازوريل و الفلافومايسين

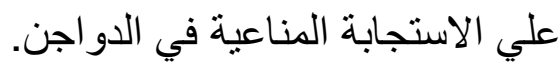

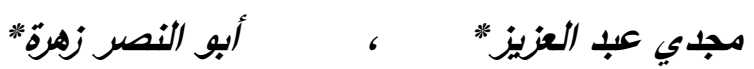

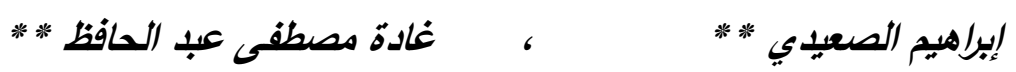

"قسم الفرماكولوجيا / كلية الطب البيطري/كفر الشيخ/ جامعة طنطا

$$
\text { * * معه بحوث صحة الحيوان - الاقي }
$$

في هذه الدراسة تم استخدام عدد ( 140 ) كتكوت هابرد عمر يوم و قد تم تقسيمها الي سبع مجاميع منساوية ( 20 كتكوت لكل مجموعة ).

وبداية من اليوم الأول:- تم إعطاء المجموعة الأولى عقار الدايكلازوريل في العليقة بجرعة

(واحد جزء من المليون) و المجموعة الثنانية تم إعطاء الدايكلازوريل في العليقة بجرعة (2 جزء في

المليون) والمجموعة الثالثة نم إعطاءها في العليقة خليط من الدايكلازوريل (واحد جزء في المليون)مع الفلافوماسين (75جرام/طن) المجموعة الرابعة تم إعطاءها (2 جزء في المليون دايكلازوريل مـع 75 جرام / طن من الفلافومايسين ) والمجموعة الخامسة تم إعطاءها 75 جرام فلافومايسين / طن و في المجموعة السادسة والسابعة تم تغذيتها عليقة فقط بدون دواء ولكن في اليوم الرابع عشر و الواحد و 
العشرين نم تحصين كل الاجاج في كل مجموعة (باستثاء المجموعة السادسة) بلقاح الجمبورو - وتم اعتبار المجموعة السادسة مجموعة ضابطة سالبة و المجموعة السابعة اعتبرت مجموعة ضابطة موجبة

وتم تحديد (5 دجاجات) من كل مجموعة عند اليوم (38) من بداية التجربة و نم إعطاءها جرعة من فيروس الجمبورو عن طريق العين و تركت للملاحظة لمدة (5 ايام). وتم تحديد (5دجاجات) أخرى من كل مجموعة عند اليوم ( 38 )من بدايـة التجربة لتحديد تجربة

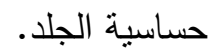
وفي نهاية التجربة تم وزن الطيور قيل الذبح وبعد الذبح نم وزن (Bursa of Fabricous). و وأوضحت النتائج الآتى:مع زيادة عقار الدايكلازوريل في العلف عمل علي تقليل المناعة حيث ان جرعة (واحد جزء في المليون )ام توثر علي مناعة الطيور علي عكس ( 2 جزء في المليون ) التي عملت علي تنبيط

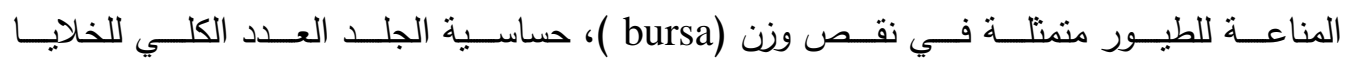
( leucocytes - lymphocytes) في بروتينات الدم و الجلوبيولين. وعلي العكس تماما فان إعطاء فلافومايسين بجرعة (75جرام /طن )لم يؤثر علي الاستجابة المناعية للطيور . n وكذلك إعطاء العقارين معا لم يحدث اي تداخل دوائي بينهما علي الاستجابة المناعية للطيور عند جرعتي (واحد جزء في المليون دايكلازوريل + 75 جرام فلافومايسين / طن). 
ولكن في الجرعة الثانية (2 جزء في المليون من الدايكلازوريل + 75 جرام فلافومايسين/طن)

(cellular

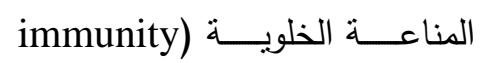
قـــــ أنقصــــت معنويــــا ف

.(humoral immunity)

و مما سبق نستخلص أن:-

إعطاء الدايكلازوريل كمضاد للكوكسيديا بجرعة (واحد جزء في المليون) أو إعطاء الفلافومايسين

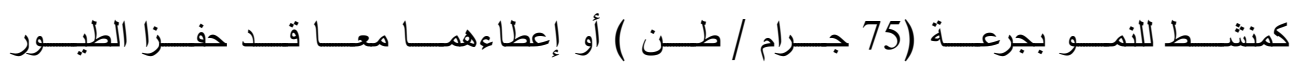
وزادا من كفاءتها. إعطـاء الـدايكلازوريل كمضـاد للكوكسيديا بجرعـة (2 جـزء في المليـون)أو عندما يعطي مـع الفلافومايسين بجرعة (75 جرام / طن ) قد عملا علي نقص الاستجابة المناعية للطيور . 